\title{
Characterization, identification and expression profiling of genome-wide $R$ - genes in melon and their putative roles in bacterial fruit blotch resistance
}

Md. Rafiqul Islam², Mohammad Rashed Hossain 1,3, Denison Michael Immanuel Jesse ${ }^{1}$, Hee-Jeong Jung ${ }^{1}$, Hoy-Taek Kim ${ }^{1}$, Jong-In Park ${ }^{1}$ and III-Sup Nou ${ }^{1 *}$ (D)

\begin{abstract}
Background: Bacterial fruit blotch (BFB), a disease caused by Acidovorax citrulli, results in significant economic losses in melon. The causal QTLs and genes for resistance to this disease have yet to be identified. Resistance $(R)$ genes play vital roles in resistance to plant diseases. Since the complete genome sequence of melon is available and genome-wide identification of $R$-genes has been performed for this important crop, comprehensive expression profiling may lead to the identification of putative candidate genes that function in the response to BFB.

Results: We identified melon accessions that are resistant and susceptible to BFB through repeated bioassays and characterized all 70 R-genes in melon, including their gene structures, chromosomal locations, domain organizations, motif distributions, and syntenic relationships. Several disease resistance-related domains were identified, including NBS, TIR, LRR, CC, RLK, and DUF domains, and the genes were categorized based on the domains of their encoded proteins. In addition, we profiled the expression patterns of the genes in melon accessions with contrasting levels of BFB resistance at $12 \mathrm{~h}, 1 \mathrm{~d}, 3 \mathrm{~d}$, and $6 \mathrm{~d}$ after inoculation with $\mathrm{A}$. citrulli. Six $R$ genes exhibited consistent expression patterns (MELO3C023441, MELO3C016529, MELO3C022157, MELO3C022146, MELO3C025518, and MELO3C004303), with higher expression levels in the resistant vs. susceptible accession.

Conclusion: We identified six putative candidate R-genes against BFB in melon. Upon functional validation, these genes could be targeted for manipulation via breeding and biotechnological approaches to improve BFB resistance in melon in the future.
\end{abstract}

Keywords: BFB, Candidate gene, Expression, Resistance, Melon, NBS-LRR, qRT-PCR

\footnotetext{
*Correspondence: nis@scnu.ac.kr; nis@sunchon.ac.kr

'Department of Horticulture, Sunchon National University, Suncheon, Jeonnam 57922, Republic of Korea

Full list of author information is available at the end of the article
}

C C The Author(s). 2020 Open Access This article is licensed under a Creative Commons Attribution 4.0 International License, which permits use, sharing, adaptation, distribution and reproduction in any medium or format, as long as you give appropriate credit to the original author(s) and the source, provide a link to the Creative Commons licence, and indicate if changes were made. The images or other third party material in this article are included in the article's Creative Commons licence, unless indicated otherwise in a credit line to the material. If material is not included in the article's Creative Commons licence and your intended use is not permitted by statutory regulation or exceeds the permitted use, you will need to obtain permission directly from the copyright holder. To view a copy of this licence, visit http://creativecommons.org/licenses/by/4.0/ The Creative Commons Public Domain Dedication waiver (http://creativecommons.org/publicdomain/zero/1.0/) applies to the data made available in this article, unless otherwise stated in a credit line to the data. 


\section{Background}

Melon (Cucumis melo L.) is a highly diversified eudicot diploid $(2 \mathrm{n}=2 \mathrm{x}=24)$ cucurbitaceous crop with a genome size of approximately $375 \mathrm{Mb}$ [1]. Melon is economically important and ranks as the 9th most cultivated horticultural crop in terms of worldwide production [2, 3]. Its sweet, musky-flavored, fleshy fruit is rich in vitamins, minerals, and health-promoting antioxidants, including ascorbic acid, carotene, folic acid, and potassium [4-6].

Melon is vulnerable to various biotic and abiotic stresses $[7,8]$. Bacterial fruit blotch (BFB) is a devastating disease of melon caused by Acidovorax citrulli, an aerobic, mesophilic, gram-negative, rod-shaped seedborne bacterium belonging to the beta subdivision of the Proteobacteria [9]. BFB has been reported in many countries and poses a serious threat to melon, as well as other cucurbit crops including prickly paddy melon, citron melon, cucumber, pumpkin, squash, several types of gourds, and watermelon [10-16]. BFB causes watersoaked lesions to form on cotyledons and leaves, leading to collapse and death. The lesions on fruits are small ( $1 \mathrm{~cm}$ diameter), irregular, and often sunken, progressing through the rind. The lesions then become necrotic, causing decay and cracks in the fruit. These lesions expose the plant to secondary infections and cause $A$. citrulli to colonize the pulp, eventually allowing the seed to become contaminated [17]. BFB causes $80-100 \%$ losses in production under favorable environmental situations, especially during the rainy season and in regions with highly fluctuating temperatures $[18,19]$. Although $\mathrm{BFB}$ is of great concern to farmers and seed companies, strategies for managing this disease are limited; chemical control measures are environmentally hazardous and only partially effective, and resistant commercial cultivars have not yet been developed [13, 20-24]. Host resistance represents the most cost effective and environmentally friendly approach for managing BFB [12]. However, no QTL or $R$-gene for this disease has thus far been identified in melon. Efforts to develop BFB-resistant melon genotypes would be greatly enhanced by the identification of functional $R$-genes.

Genomic studies have provided insight into the evolution of $R$-genes, which play important roles in the plant immune system in response to various pathogens and insects [25]. Plant $R$-genes encode proteins containing domains such as Nucleotide-binding site (NBS), Leucine-rich repeat (LRR), Toll/interleukin-1 receptor (TIR), Coiled-coil (CC), and Receptor-like kinase (RLK) domains [26-32]. These domains are involved in pathogen recognition, signaling, and plant innate immunity responses [26, 27, 29, 31-35]. $R$-genes have been identified in the genomes of plant species including watermelon [36], cucumber [25], rice [37, 38], Chinese cabbage [39], maize [40], wheat [41], Arabidopsis thaliana [42], and apple [43].

An improved assembly and annotation of the melon (Cucumis melo L.) reference genome identified $70 \mathrm{R}$ genes in melon $[1,44,45]$. In the current study, we investigated the expression patterns of $R$-genes throughout the melon genome in response to the BFB-causing bacterium A. citrulli in melon accessions contrasting in BFB resistance. The aim of this study was to identify putative candidate $R$-genes that confer resistance to $\mathrm{BFB}$ in melon.

\section{Results}

Genome-wide melon $R$-genes and their chromosomal distribution

The latest version (v3.6.1) of the whole-genome sequence of the melon double haploid line DHL90 was constructed using an improved assembly and annotation. This sequence contains $70 R$-genes $[1,44]$. We retrieved genomic information for these $70 R$-genes, including their coding sequences and deduced amino acid sequences, from the cucurbit genome database (http:// cucurbitgenomics.org). Detailed genomic information about these $R$-genes, including their locations on chromosomes, is provided in Table 1. Chromosomal mapping of the $70 R$-genes revealed that they are distributed across all 12 melon chromosomes, with 1 to 12 genes per chromosome (Fig. 1; Table 1). Chromosome 9 (Chr09) contains the most $R$-genes (12), followed by Chr12 and Chr01 (10 and 9 genes, respectively). Chr11 contains the fewest $R$-genes (2), followed by $\mathrm{Chr03}$ and Chr07 (3 genes each). The genes appear to be clustered, particularly in the telomere regions of chromosomes such as chr09, chr01, and chr04 (Fig. 1).

\section{Gene structures, domain organizations, and motif distribution of $R$-genes in melon}

We analyzed the exon-intron structures of all 70 melon $R$-genes by comparing their coding sequences with the corresponding genomic sequences using the online tool GSDS2.0 (http://gsds.cbi.pku.edu.cn/). The highest number of exons (22) was in the gene MELO3C013803, followed by 18 in MELO3C007367 (Additional file 1: Fig. $\mathrm{S} 1)$. Among the $70 \mathrm{R}$-genes, 21 were mono-exonic, while 12 and 4 genes were bi- and tri-exonic, respectively.

We analyzed the conserved domains of the 70 melon $R$ genes using the Conserved Domain Database (CDD) at https://www.ncbi.nlm.nih.gov/Structure/bwrpsb/bwrpsb.cgi.

We detected several disease resistance-related domains encoded by these $R$-genes, such as NB-ARC (Nucleotidebinding adaptor shared by APAF-1, R proteins, and CED-4), LRR (Leucine-rich repeat), TIR (Toll/interleukin-1 receptor), CC (Coiled-coil), and RLK (Receptor-like kinase) domains. The $R$-genes were grouped into different classes based on 
Table 1 Information about $R$-genes throughout the melon genome including chromosomal positions, lengths, and annotated descriptions

\begin{tabular}{|c|c|c|c|c|c|c|c|c|}
\hline \multirow[t]{2}{*}{$\mathrm{SI}}$. & \multirow[t]{2}{*}{ Gene ID ${ }^{a}$} & \multirow{2}{*}{$\begin{array}{l}\text { Chr. } \\
\text { Number }\end{array}$} & \multicolumn{2}{|c|}{ Position on chromosome } & \multirow{2}{*}{$\begin{array}{l}\text { CDS- } \\
\text { length } \\
\text { (bp) }\end{array}$} & \multirow{2}{*}{$\begin{array}{l}\text { Peptide } \\
\text { length } \\
\text { (AA) }\end{array}$} & \multirow[t]{2}{*}{ Strand } & \multirow[t]{2}{*}{ Description } \\
\hline & & & Start & End & & & & \\
\hline 1 & MELO3C023580.2 & chr01 & $33,386,823$ & $33,390,698$ & 687 & 288 & - & Disease-resistance protein RGA2-like \\
\hline 2 & MELO3C023579.2 & chr01 & $33,395,126$ & $33,397,789$ & 2664 & 887 & - & Disease-resistance protein RGA2-like isoform $\mathrm{X} 1$ \\
\hline 3 & MELO3C023578.2 & chr01 & $33,410,087$ & $33,414,749$ & 1158 & 385 & - & Disease-resistance protein \\
\hline 4 & MELO3C023577.2 & chr01 & $33,419,963$ & $33,423,566$ & 2715 & 904 & - & Disease-resistance protein RGA2-like \\
\hline 5 & MELO3C023441.2 & chr01 & $34,457,351$ & $34,462,055$ & 2766 & 921 & - & Receptor-kinase, putative \\
\hline 6 & MELO3C023440.2 & chr01 & $34,462,521$ & $34,463,915$ & 1338 & 445 & - & LRR receptor-like serine/threonine-protein kinase GSO2 \\
\hline 7 & MELO3C023439.2 & chr01 & $34,468,416$ & $34,473,193$ & 3207 & 1068 & - & LRR receptor-like serine/threonine-protein kinase GSO2 \\
\hline 8 & MELO3C023438.2 & chr01 & $34,474,924$ & $34,475,353$ & 336 & 111 & + & LRR receptor-like serine/threonine-protein kinase GSO2 \\
\hline 9 & MELO3C023437.2 & chr01 & $34,475,729$ & $34,476,367$ & 354 & 117 & + & Receptor-kinase, putative \\
\hline 10 & MELO3C029319.2 & chr02 & $4,111,584$ & $4,115,605$ & 717 & 238 & + & NBS-LRR type resistance protein \\
\hline 11 & MELO3C015353.2 & chr02 & 985,162 & 987,242 & 1737 & 578 & + & Disease-resistance protein RGA2-like \\
\hline 12 & MELO3C015354.2 & chr02 & 990,582 & 993,823 & 3240 & 1080 & + & Disease-resistance protein RGA2-like \\
\hline 13 & MELO3C029505.2 & chr02 & $7,359,371$ & $7,363,388$ & 765 & 254 & - & TMV resistance protein $\mathrm{N}$-like \\
\hline 14 & MELO3C010346.2 & chr02 & $17,481,683$ & $17,485,283$ & 1593 & 530 & + & TMV resistance protein $\mathrm{N}$ \\
\hline 15 & MELO3C010827.2 & chr03 & $30,596,169$ & $30,600,072$ & 3663 & 1054 & - & Receptor-kinase, putative \\
\hline 16 & MELO3C010826.2 & chr03 & $30,600,299$ & $30,603,794$ & 3054 & 1071 & - & Receptor-kinase, putative \\
\hline 17 & MELO3C010825.2 & chr03 & $30,604,364$ & $30,611,770$ & 6069 & 2022 & - & Receptor-kinase, putative \\
\hline 18 & MELO3C009695.2 & chr04 & $30,097,463$ & $30,100,144$ & 2682 & 893 & + & Disease-resistance protein \\
\hline 19 & MELO3C009694.2 & chr04 & $30,103,601$ & $30,106,071$ & 2391 & 796 & + & Disease-resistance protein \\
\hline 20 & MELO3C009693.2 & chr04 & $30,110,724$ & $30,113,156$ & 2358 & 786 & + & Disease-resistance protein \\
\hline 21 & MELO3C009179.2 & chr04 & $33,763,652$ & $33,766,776$ & 3042 & 1013 & + & Receptor-kinase, putative \\
\hline 22 & MELO3C009177.2 & chr04 & $33,766,795$ & $33,780,875$ & 3231 & 1076 & + & Receptor-kinase, putative \\
\hline 23 & MELO3C004259.2 & chr05 & $25,752,437$ & $25,757,292$ & 3951 & 1316 & + & TMV resistance protein $\mathrm{N}$-like isoform $\mathrm{X} 1$ \\
\hline 24 & MELO3C004288.2 & chr05 & $26,044,574$ & $26,052,361$ & 3171 & 1056 & + & TMV resistance protein $\mathrm{N}$-like \\
\hline 25 & MELO3C004289.2 & chr05 & $26,065,157$ & $26,071,880$ & 3867 & 1288 & - & TMV resistance protein $\mathrm{N}$-like \\
\hline 26 & MELO3C004301.2 & chr05 & $26,231,021$ & $26,237,770$ & 4032 & 1343 & - & TMV resistance protein $\mathrm{N}$-like isoform $\mathrm{X} 1$ \\
\hline 27 & MELO3C004303.2 & chr05 & $26,239,395$ & $26,244,020$ & 2052 & 683 & - & TMV resistance protein $\mathrm{N}$-like \\
\hline 28 & MELO3C004309.2 & chr05 & $26,263,738$ & $26,270,641$ & 4134 & 1377 & + & TMV resistance protein $\mathrm{N}$-like \\
\hline 29 & MELO3C004311.2 & chr05 & $26,280,801$ & $26,299,171$ & 3156 & 1051 & - & TMV resistance protein $\mathrm{N}$-like \\
\hline 30 & MELO3C004313.2 & chr05 & $26,311,869$ & $26,315,091$ & 2115 & 704 & - & TMV resistance protein $\mathrm{N}$-like \\
\hline 31 & MELO3C006780.2 & chr06 & $5,898,974$ & $5,902,420$ & 3447 & 1148 & - & Disease-resistance protein \\
\hline 32 & MELO3C006801.2 & chr06 & $6,106,483$ & $6,109,133$ & 846 & 281 & - & Protein enhanced disease resistance 2-like \\
\hline 33 & MELO3C016529.2 & chr06 & $27,910,808$ & $27,913,125$ & 504 & 167 & - & TMV resistance protein $\mathrm{N}$ \\
\hline 34 & MELO3C013803.2 & chr06 & $33,588,343$ & $33,599,894$ & 2184 & 727 & + & Protein enhanced disease resistance 2 \\
\hline 35 & MELO3C017700.2 & chr07 & $26,469,746$ & $26,473,637$ & 3141 & 1046 & - & Disease-resistance protein RGA2-like \\
\hline 36 & MELO3C017701.2 & chr07 & $26,475,401$ & $26,480,759$ & 3192 & 1063 & + & Disease-resistance protein RGA2-like \\
\hline 37 & MELO3C017703.2 & chr07 & $26,480,404$ & $26,483,226$ & 2823 & 940 & - & Disease-resistance protein RGA2-like \\
\hline 38 & MELO3C007354.2 & chr08 & $2,332,143$ & $2,335,108$ & 1806 & 601 & - & Cysteine-rich receptor-like protein kinase 29 \\
\hline 39 & MELO3C007358.2 & chr08 & $2,346,707$ & $2,353,661$ & 4296 & 1431 & - & Receptor-like protein kinase \\
\hline 40 & MELO3C007360.2 & chr08 & $23,53,788$ & $2,361,267$ & 4088 & 1395 & - & Receptor-like protein kinase \\
\hline 41 & MELO3C007367.2 & chr08 & $2,372,510$ & $2,386,472$ & 4656 & 1551 & - & Receptor-like kinase \\
\hline 42 & MELO3C022157.2 & chr09 & 665,753 & 668,864 & 2025 & 674 & - & TMV resistance protein $\mathrm{N}$-like isoform $\mathrm{X} 1$ \\
\hline
\end{tabular}


Table 1 Information about $R$-genes throughout the melon genome including chromosomal positions, lengths, and annotated descriptions (Continued)

\begin{tabular}{|c|c|c|c|c|c|c|c|c|}
\hline \multirow[t]{2}{*}{$\mathrm{SI}$} & \multirow[t]{2}{*}{ Gene $I D^{a}$} & \multirow{2}{*}{$\begin{array}{l}\text { Chr. } \\
\text { Number }\end{array}$} & \multicolumn{2}{|c|}{ Position on chromosome } & \multirow{2}{*}{$\begin{array}{l}\text { CDS- } \\
\text { length } \\
\text { (bp) }\end{array}$} & \multirow{2}{*}{$\begin{array}{l}\text { Peptide } \\
\text { length } \\
(A A)\end{array}$} & \multirow[t]{2}{*}{ Strand } & \multirow[t]{2}{*}{ Description } \\
\hline & & & Start & End & & & & \\
\hline 43 & MELO3C022154.2 & chr09 & 681,564 & 689,908 & 3432 & 1143 & - & TMV resistance protein $\mathrm{N}$-like \\
\hline 44 & MELO3C022152.2 & chr09 & 700,743 & 713,705 & 4173 & 1390 & + & TMV resistance protein $\mathrm{N}$-like \\
\hline 45 & MELO3C022146.2 & chr09 & 762,107 & 767,613 & 2274 & 757 & - & TMV resistance protein $\mathrm{N}$-like \\
\hline 46 & MELO3C022145.2 & chr09 & 768,255 & 784,265 & 3807 & 1268 & + & TMV resistance protein $\mathrm{N}$-like \\
\hline 47 & MELO3C022144.2 & chr09 & 784,629 & 792,999 & 4902 & 1633 & - & TMV resistance protein $\mathrm{N}$-like \\
\hline 48 & MELO3C025516.2 & chr09 & $6,632,514$ & $6,659,697$ & 4371 & 1,456 & - & TMV resistance protein $\mathrm{N}$-like \\
\hline 49 & MELO3C025519.2 & chr09 & $6,674,960$ & $6,677,738$ & 762 & 253 & - & Disease-resistance protein RGA2-like \\
\hline 50 & MELO3C025518.2 & chr09 & $6,675,092$ & $6,676,395$ & 648 & 215 & - & Disease-resistance protein RGA2-like \\
\hline 51 & MELO3C005450.2 & chr09 & $21,691,401$ & $21,694,271$ & 2790 & 929 & - & LRR receptor-like kinase family protein \\
\hline 52 & MELO3C005451.2 & chr09 & $21,699,468$ & $21,702,467$ & 3000 & 999 & - & LRR receptor-like kinase \\
\hline 53 & MELO3C005452.2 & chr09 & $21,708,265$ & $21,711,353$ & 28,17 & 938 & - & LRR receptor-like kinase \\
\hline 54 & MELO3C012268.2 & chr10 & $1,574,521$ & $1,579,615$ & 1800 & 599 & + & $\begin{array}{l}\text { Leaf rust } 10 \text { disease-resistance locus receptor-like } \\
\text { protein kinase-like } 1.2 \text { isoform X4 }\end{array}$ \\
\hline 55 & MELO3C012049.2 & chr10 & $2,989,020$ & $2,990,934$ & 1869 & 622 & + & $\begin{array}{l}\text { Leaf rust } 10 \text { disease-resistance locus receptor-like } \\
\text { protein kinase-like } 1.5\end{array}$ \\
\hline 56 & MELO3C012045.2 & chr10 & $3,007,893$ & $3,014,091$ & 1503 & 500 & - & Protein enhanced disease resistance 2 \\
\hline 57 & MELO3C034399.2 & chr10 & $15,627,727$ & $15,627,921$ & 195 & 64 & + & Disease-resistance protein At4g27190-like \\
\hline 58 & MELO3C022580.2 & chr10 & $16,222,411$ & $16,222,859$ & 447 & 148 & - & Disease-resistance protein RGA2-like \\
\hline 59 & MELO3C022447.2 & chr11 & $33,758,671$ & $33,762,610$ & 3030 & 1009 & - & Receptor-like protein \\
\hline 60 & MELO3C022449.2 & chr11 & $33,770,307$ & $33,772,966$ & 2145 & 714 & - & Receptor-like protein \\
\hline 61 & MELO3C002671.2 & chr12 & $22,199,381$ & $22,201,102$ & 1350 & 449 & + & LRR receptor-like kinase \\
\hline 62 & MELO3C002667.2 & chr12 & $22,209,961$ & $22,215,123$ & 3279 & 1092 & + & LRR receptor-like kinase \\
\hline 63 & MELO3C002666.2 & chr12 & $22,219,699$ & $22,226,478$ & 3114 & 1037 & + & LRR receptor-like kinase \\
\hline 64 & MELO3C002506.2 & chr12 & $23,598,469$ & $23,607,646$ & 2040 & 679 & - & Receptor-like protein kinase \\
\hline 65 & MELO3C002504.2 & chr12 & $23,611,543$ & $23,620,880$ & 3870 & 1289 & - & Cysteine-rich receptor-like protein kinase 28 \\
\hline 66 & MELO3C002501.2 & chr12 & $23,633,920$ & $23,636,908$ & 1617 & 538 & + & $\begin{array}{l}\text { Cysteine-rich receptor-like protein kinase } \\
26 \text { isoform X1 }\end{array}$ \\
\hline 67 & MELO3C002394.2 & chr12 & $24,343,418$ & $4,346,595$ & 2385 & 794 & - & LRR receptor-like kinase family protein \\
\hline 68 & MELO3C002393.2 & chr12 & $24,352,898$ & $4,355,087$ & 2190 & 729 & - & LRR receptor-like kinase \\
\hline 69 & MELO3C002392.2 & chr12 & $24,358,807$ & $24,361,890$ & 3084 & 1027 & - & $\begin{array}{l}\text { LRR receptor-like serine/threonine- } \\
\text { protein kinase GSO1 }\end{array}$ \\
\hline 70 & MELO3C002389.2 & chr12 & $24,376,328$ & $24,380,811$ & 3786 & 1261 & + & LRR receptor-like serine/threonine-protein kinase GSO1 \\
\hline
\end{tabular}

a Genomic information based on the reference Genome of Melon (DHL92) v3.6.1 retrieved from the Cucurbit Genomics Database (http://cucurbitgenomics.org)

the presence of the following conserved domains in their encoded proteins: (i) LRR, (ii) NBS-LRR, (iii) TIR, (iv) TIR-NBS-LRR, (v) NB-ARC, (vi) CC, (vii) RLK, and (viii) DUF (Table 2 and Additional file 1: Fig. S2). Thirty-seven genes encoded proteins with only LRR domains, seven encoded proteins with NBARC domains, two encoded proteins with TIR domains, and only one encodes a protein with a CC domain (Table 2). Twelve genes encoded three domains (TIR, NBS, and LRR), including MELO3C004288, MELO3C004289, MELO3C004311, MELO3C004313, MELO3C022154, MELO3C022152, MELO3C022146,
MELO3C022145, MELO3C022144, MELO3C004309, MELO3C004259, and MELO3C004301. A list of the genes and a description of their domains is provided in Table 2.

We analyzed the conserved motifs of these $70 R$-genes using the MEME Suite (http://meme-uite.org/tools/ meme). A total of 20 conserved motifs were detected in these $70 R$-genes, each comprising more than 14 amino acids. The greatest number of motifs was identified in the LRR domain-encoding gene MELO3C002394, whereas the fewest were detected in MELO3C029505, MELO3C023580, and MELO3C006801, which are LRR-, 


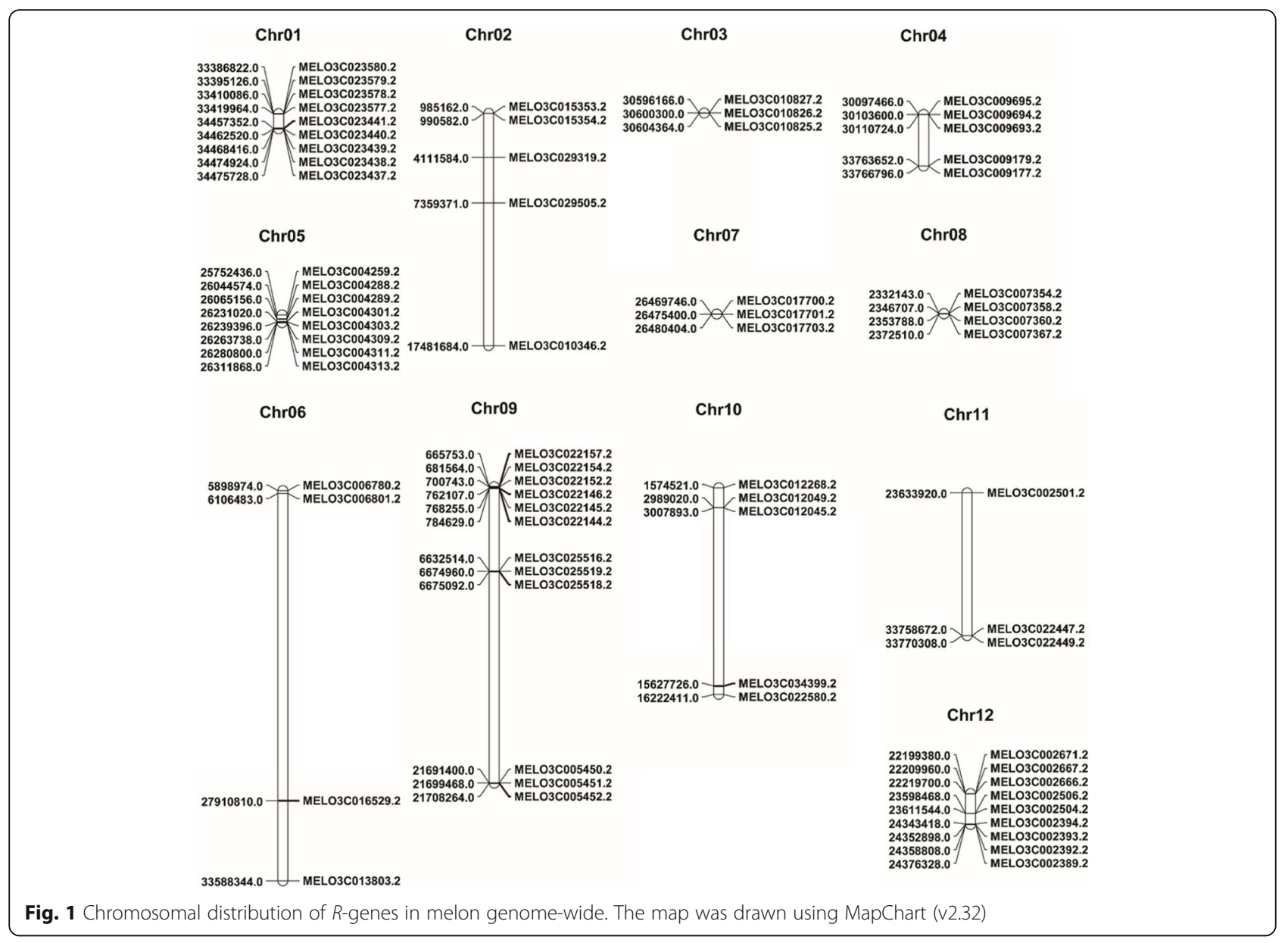

CC-, and DUF-domain-encoding genes, respectively. The distribution of these conserved motifs, along with the motif sequences, is described in Fig. 2.

\section{Microsynteny of melon $R$-genes with genes in the watermelon and cucumber genomes}

We analyzed the microsyntenic relationships of the 70 $R$-genes from melon (Cucumis melo) with genes in the watermelon (Citrullus lanatus) and cucumber (Cucumis sativus) genomes using the Circos tool. Most $R$-genes from melon were homologous to $R$-genes from watermelon and cucumber. However, watermelon $R$-genes on chromosomes 11 and 12 lacked homologues in melon (Fig. 3). By contrast, all 70 R-genes in melon had homologues in all chromosomes of cucumber.

\section{Expression profiles of melon $R$-genes in response to $A$. citrulli inoculation}

We investigated the expression patterns of the 70 melon $R$-genes in the leaves of resistant and susceptible melon seedlings at $12 \mathrm{~h}, 1 \mathrm{~d}, 3 \mathrm{~d}$, and $6 \mathrm{~d}$ of inoculation with $A$. citrulli strain NIHHS15-280 via qRT-PCR. Several genes showed differential expression in the resistant vs. susceptible accession at different time points. A general trend of low expression for these genes was observed in the susceptible accession (Fig. 4). On the contrary, most of the genes were significantly induced within $12 \mathrm{~h}$ of $A$. citrulli infection in the resistant accession and showed a general increase in expression in this accession. By contrast, in the susceptible accession, the expression of these genes fluctuated, with little or no expression at the $12 \mathrm{~h}$ time point. Heatmap analysis of the expression data identified a sub-cluster of six genes (MELO3C023441, MELO3C016529, MELO3C022157, MELO3C022146, MELO3C025518, and MELO3C004303) that showed contrasting trends of expression in the resistant vs. susceptible accession, with progressively increasing expression after inoculation with $A$. citrulli in the resistant but not the susceptible accession (Fig. 4). Extensive analysis of these six genes indicated that the expression of four genes (MELO3C023441, MELO3C004303, MELO3C022146, and MELO3C025518) increased in the resistant accession with increasing time after inoculation with $A$. citrulli (Fig. 5). In the susceptible accession, the expressions of these genes were very low in the initial hours after inoculation and did not show significant increase over time after 
Table 2 R-genes throughout the melon genome categorized based on functional disease resistance-related domains

\begin{tabular}{lll}
\hline SI. Domain & Function & Gene ID \\
\hline 1 & Leucine-rich repeat $(L R R)$ & MELO3C023577.2, MELO3C023579.2, MELO3C015353.2, \\
& Recognition of pathogen \\
and Plant Defense $[29,46]$ & MELO3C015354.2, MELO3C017700.2, MELO3C017701.2, \\
& & MELO3C025518.2, MELO3C009695.2, MELO3C006780.2, \\
& MELO3C023441.2, MELO3C023437.2, MELO3C023440.2, \\
& MELO3C023439.2, MELO3C023438.2, MELO3C004303.2, \\
& MELO3C025516.2, MELO3C010346.2, MELO3C005450.2, \\
& MELO3C002394.2, MELO3C005451.2, MELO3C005452.2, \\
& MELO3C002671.2, MELO3C002667.2, MELO3C022447.2, \\
& MELO3C022449.2, MELO3C002392.2, MELO3C002389.2, \\
& MELO3C002393.2, MELO3C029505.2, MELO3C034399.2, \\
& MELO3C010827.2, MELO3C010826.2, MELO3C010825.2, \\
& MELO3C009179.2, MELO3C009177.2, MELO3C007367.2, \\
& MELO3C002666.2
\end{tabular}

2 Nucleotide-binding site leucine-rich repeat (NBS-LRR)

3 Toll/interleukin-1 receptor homology (TIR)

4 Toll/interleukin-1 receptor homology nucleotide-binding site leucine-rich repeat (TIR-NBS-LRR)

$5 \quad$ Nucleotide-binding adaptor shared by APAF- $1, R$ proteins and CED- 4 (NB-ARC)

6 Coiled-coil domain (CC)

$7 \quad$ Protein kinase (RLK)

8 Domain of unknown function (DUF)
Resistance protein Signaling and Plant Defense $[27,33,47]$

TMV resistance protein N [34, 46]

Pathogen specificity and defense $[34,46,48]\{$ Nandety, 2013 \#111\}

Molecular switch in activating defenses [28, 31]

Pathogen recognition and signaling [31, 32, 49]

Signaling and plant defense [35, 50-52]

Protein enhanced disease resistance 2-like $[53,54]$
MELO3C029319.2

\section{MELO3C022157.2, MELO3C016529.2}

MELO3C004288.2, MELO3C004289.2, MELO3C004311.2, MELO3C004313.2, MELO3C022154.2, MELO3C022152.2, MELO3C022146.2, MELO3C022145.2, MELO3C022144.2, MELO3C004309.2, MELO3C004259.2, MELO3C004301.2,

MELO3C017703.2, MELO3C025519.2, MELO3C022580.2, MELO3C023578.2, MELO3C009694.2, MELO3C009693.2, MELO3C013803.2

MELO3C023580.2

MELO3C007354.2, MELO3C007358.2, MELO3C007360.2, MELO3C002506.2, MELO3C012268.2, MELO3C012049.2, MELO3C002504.2, MELO3C002501.2

MELO3C006801.2, MELO3C012045.2 inoculation. In the resistant accession, the expression of these four genes (MELO3C023441, MELO3C004303, MELO3C022146, and MELO3C025518) peaked at $6 \mathrm{~d}$ after inoculation, with levels approximately 8-, 8-, 10-, and 7 -fold those of the control samples, respectively. In the susceptible accession, the expression of two of these genes did not increase in response to $A$. citrulli inoculation, whereas the expression of two genes (MELO3C022157 and MELO3C016529) generally increased in response to inoculation, but to a lesser extent than in the resistant accession. The expression of these two genes increased until $3 \mathrm{~d}$ after inoculation (5-fold in MELO3C016529 and 2.5fold in MELO3C022157), followed by a decrease to their lowest levels at $6 \mathrm{~d}$ post inoculation (Fig. 5).

\section{Discussion}

Here, we identified $R$-genes with putative roles in resistance to BFB disease in melon by profiling the genomewide expression patterns of $R$-genes from melon in response to inoculation with $A$. citrulli. Disease resistance in plants involves the interaction between specific disease resistance $(R)$-genes in plants and avirulence (avr) genes of the pathogen which is known as gene-for-gene model $[55,56]$. Most plant $R$-genes belong to a superfamily of genes encoding proteins with an NBS or LRR domain, an N-terminal TIR or CC domain, or an RLK/ RLP domain $[29,57]$. A meta-analysis of the 314 cloned plant $R$-genes revealed that 191 (61\%) such genes are NBS-LRR genes and 60 (19\%) genes are RLKs/RLPs [58]. NBS domains bind to and hydrolyze adenosine triphosphate (ATP) or guanosine triphosphate (GTP) and are involved in signaling; LRR domains are highly adaptable structural domains that are responsible for protein-protein interactions and play an important role in plantpathogen recognition [59]; TIR domains provide pathogen specificity and plant defense responses, while CC domains are involved in pathogen recognition and signaling; and RLK domains play roles in signaling and plant defense responses.

In melon, four resistance gene homologue sequences were previously reported that contained 14 TIR-NBSLRR genes [60, 61]. A study of the first complete genome sequence of melon identified 411 putative $R$-genes, including 161 RLKs, 110 RLP (receptor-like proteins) genes, 19 RLK-GNK2 (kinases containing an additional antifungal protein ginkbilobin-2 domain) genes, and 81 genes containing canonical resistance domains, such as NBS, LRR, and TIR domains [1]. Among these genes, 25 were homologous to Pto genes from tomato and 15 were homologous to Mlo genes from barley [62, 63]. After 


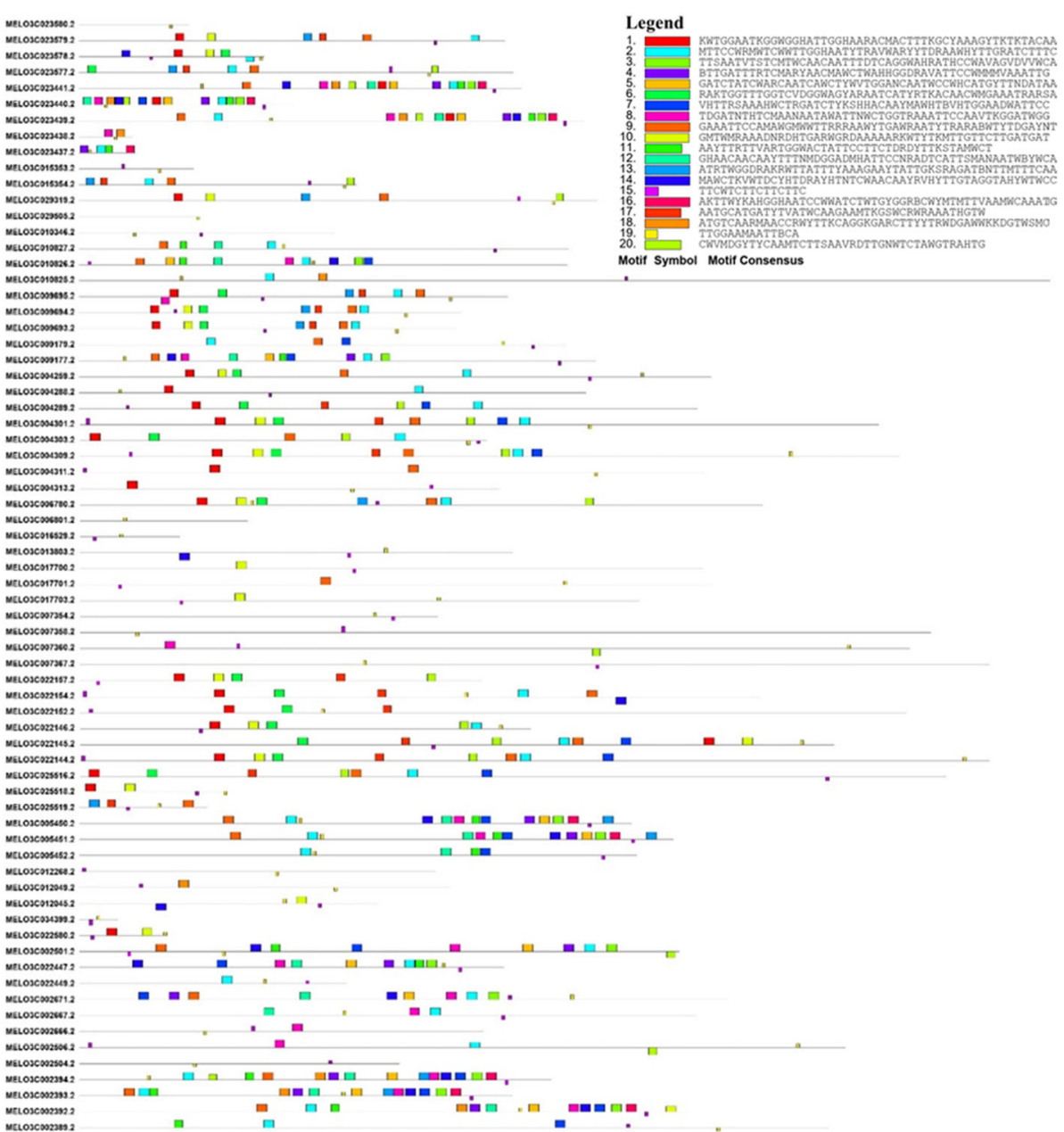

Fig. 2 Conserved motifs in the R-genes of melon. Motifs are indicated by different colored rectangles. Motif sequences are provided in the legend

further improvements in the assembly and annotation of the melon (Cucumis melo L.) reference genome, $70 \mathrm{R}$ genes were ultimately identified in melon [44].

Our comprehensive in-silico analysis of the 70 melon $R$-genes revealed that they encode proteins with several disease resistance-related domains, including LRR, NBS, TIR, NB-ARC, CC, RLK, and DUF domains (Table 2). These genes are distributed across all melon chromosomes, and some are clustered in the telomeric regions of a few chromosomes (Fig. 1). The clustering of R-genes is an evolutionarily conserved defense mechanism in plants wherein recombination in closely located genes creates new motif combinations, which generates novel resistance specificities and broadens plant resistance to different diseases $[42,64]$. $R$-gene clusters that provide resistance to multiple diseases have been reported for angular leaf spot, downy mildew, and anthracnose diseases in cucumber [65] and for blackleg, sclerotinia stem rot, and clubroot diseases in B. napus [66-68] and B. rapa [66]. In melon, a
$1 \mathrm{Mb}$ region on chromosome five contains the highest density of $R$-genes [69]. In addition, a cluster of 13 TNL genes is located in the same region as the melon Vat resistance gene [70], and another cluster of 7 TNL genes is located in the region harboring the Fom-1 resistance gene [71]. The Vat locus encodes a CC-NBS-LRR protein that confers resistance to aphid and aphid-mediated viruses in melon. The loss of two highly conserved LRRs is linked with susceptibility to these viruses [72]. In addition, the Fusarium wilt resistance locus Fom-2 is a TIR-NBS-LRR gene [73]. Expression patterns of the genome-wide $R$-genes are thus studied to identify any potential candidate genes against $A$. citrulli.

Six melon genes were highly expressed in the BFBresistant accession. Of these genes, three (MELO3C016529, MELO3C022157, and MELO3C022146) are TNL genes, two (MELO3C023441 and MELO3C025518) are LRR genes, and one (MELO3C005452) is an NBS-LRR gene (Table 2). These genes were highly expressed at $6 \mathrm{~d}$ after 


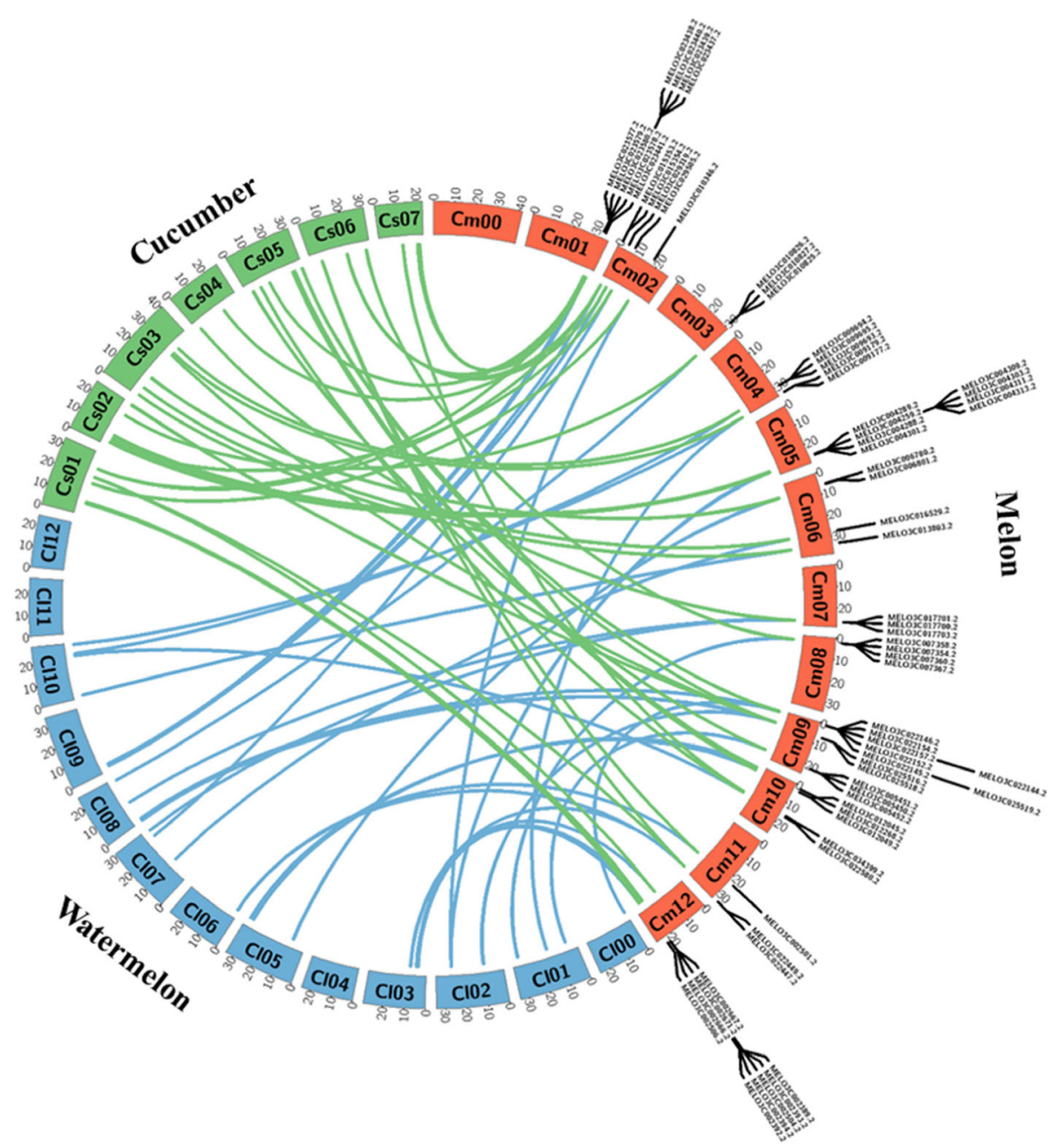

Fig. 3 Microsynteny analysis of all 70 melon R-genes with those of watermelon and cucumber. Melon, watermelon, and cucumber chromosomes are shown in orange, blue, and green, respectively. The diagram was drawn using the web-based tool Circos (http://circos.ca/software/download/) circos-0.69-9.tgz

inoculation (Fig. 5), which is consistent with our observation that BFB symptoms first appeared at 6-7 $\mathrm{d}$ in a susceptible accession [74].

Expression analysis upon infection with $A$. citrulli indicated a general trend of low expression for most $R$-genes in susceptible accession. By contrast, a set of genes including MELO3C023441, MELO3C004303, MELO3C022146, and MELO3C025518 were expressed at much higher levels, and MELO3C022157 and MELO3C016529 were expressed at relatively higher levels, (Fig. 5) in the resistant accession. Such higher expression in response to A. citrulli in the resistant accession indicates the potential involvement of these $R$-genes in BFB resistance in melon.

Several comparative transcriptomic studies have been reported in melon [75-77], but few studies have focused exclusively on expression profiling of $R$-genes against phytopathogenic agents in melon. For example, RNA-seq assessment of the changes in transcript levels at different time points in Phytophthora capsici-inoculated tissues of resistant and susceptible melon genotypes provided a basis for identifying candidate resistant genes [78]. Comparative transcriptome analysis identified ten genes that were differentially expressed in resistant and susceptible cultivars of melon in response to powdery mildew [79]. In addition, a study of the $M L O$ (mildew resistance locus o) gene family in melon revealed candidate genes that might play roles in susceptibility to powdery mildew [80]. In watermelon, six NBS-encoding $R$-genes were identified as candidates for gummy stem blight (GSB) resistance $[81,82]$. Finally, markers have been developed for detecting both GSB and BFB resistance in melon based on the sequence polymorphism in the TIR-NBS-LRR gene MELO3C022157 [81, 83]. Notably, all six candidate $R$ genes identified in the current study have corresponding homologues in watermelon and cucumber (Fig. 3). The 


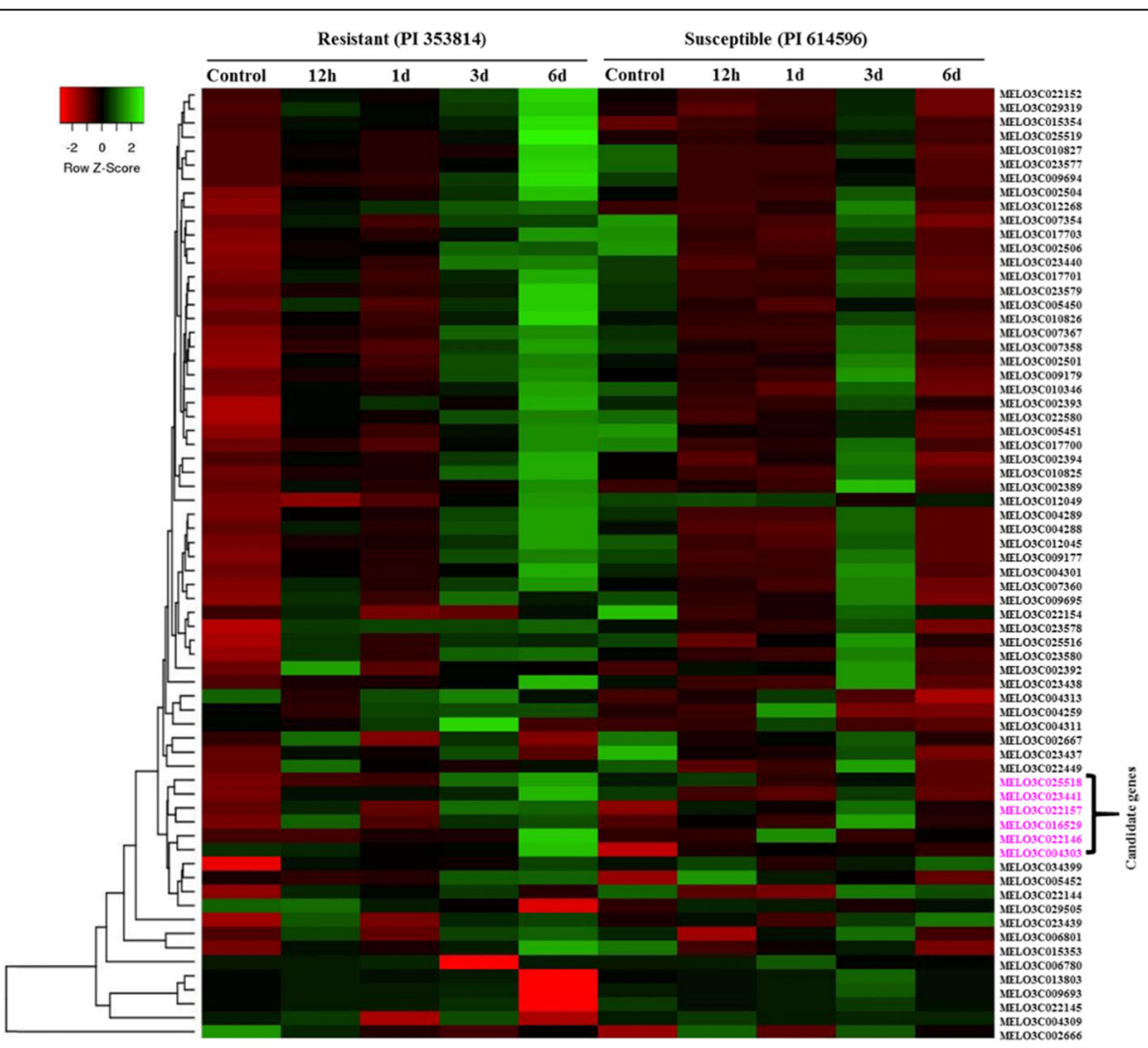

Fig. 4 Heat map of the expression patterns of melon R-genes determined by qRT-PCR in BFB-resistant and -susceptible melon accessions at the indicated time points after inoculation with A. citrulli. The expression levels were normalized to that Actin (the expression levels of the Actin gene are shown in Additional file 1: Fig. S3). The values were obtained from the means of three biological replicates. Red and green represent the minimum and maximum values, respectively. The IDs of six putative $R$-genes are shown in pink on the right side of the figure. MELO3C002671 and MELO3C022447 were not expressed and are therefore not shown in the heatmap. The heat map was generated using the online tool Heatmapper (http://www.heatmapper.ca/expression/)
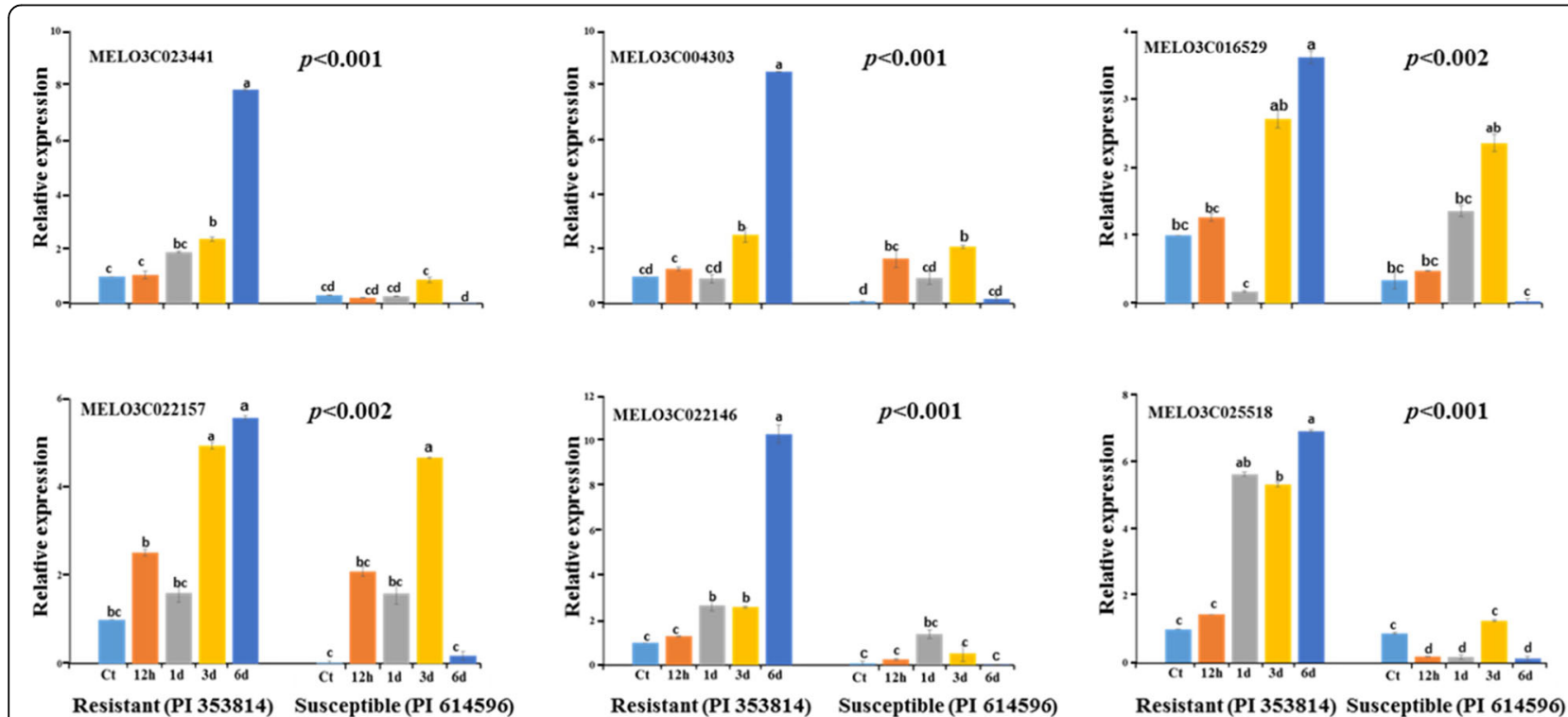

Resistant (PI 353814) Susceptible (PI 614596)

Resistant (PI 353814) Susceptible (PI 614596)

Resistant (PI 353814) Susceptible (PI 614596)

Fig. 5 Relative expression levels of six candidate $R$-genes in resistant and susceptible melon accessions at the indicated time points after inoculation with A. citrulli. Error bars represent standard errors of three individual observations. Different letters above the bars indicate significant differences, as determined by Tukey's pairwise comparison. Ct-control, h- hour, and d- day 
roles of these genes in BFB resistance in these two crops remain to be investigated.

\section{Conclusions}

We identified six putative candidate genes that might play roles in resistance to BFB in melon. This is the first report of candidate genes for BFB resistance in melon. Our findings provide a basis for further functional studies to validate the exact roles of these genes. In addition, causal sequence polymorphisms could be identified in these genes, leading to the development of markers for $B F B$ resistance. Our findings will thus be useful for improving the $\mathrm{BFB}$ resistance trait in melon.

\section{Methods}

A. citrulli: collection, culture, and inoculum preparation A. citrulli strain NIHHS15-280 was obtained from the National Institute of Horticultural and Herbal Science (NIHHS), South Korea. The bacterium was cultured on Petri plates containing $20 \mathrm{ml}$ King's B (KB) medium supplemented with $100 \mu \mathrm{g} \mathrm{ml}^{-1}$ ampicillin for $36-48 \mathrm{~h}$ at $28^{\circ} \mathrm{C}$ [84] until bacterial colonies formed. For all inoculations, a bacterial suspension was prepared by covering the culture plates with $5 \mathrm{ml}$ of sterile, double distilled (DD) water and gently scraping the surface of the KB medium using an L-shaped rubber spreader to an optical density (OD) of 1.0 at $600 \mathrm{~nm}$, as measured using a NanoDrop ND-1000 Spectrophotometer. The bacterial suspension was diluted to a final concentration of $\sim 1 \times$ $10^{6}$ colony forming units $(\mathrm{cfu}) \mathrm{mL}^{-1}$.

\section{Plant materials, growth conditions, and bioassays}

The BFB-resistant (PI 353814) and -susceptible (PI 614596) melon accessions [74, 85] used in this study were obtained from the U.S. National Plant Germplasm System (https://npgsweb.ars-grin.gov/gringlobal/search. aspx), USDA, USA. The seeds were sown in a commercial nursery soil mixture in 32-cell trays and grown in a controlled plant growth chamber at $25 \pm 2{ }^{\circ} \mathrm{C}, 16 \mathrm{~h}$ day length, relative humidity of $60 \%$, and a light intensity of $440 \mu \mathrm{moles} / \mathrm{m}^{2} / \mathrm{s}$ at bench level. After 3 weeks, the plants were transferred to a greenhouse.

Two weeks after germination, the plants were transferred to plastic pots and grown in a greenhouse at $24 \pm$ $2{ }^{\circ} \mathrm{C}$ with a relative humidity of $90 \%$ where the plants were inoculated with $A$. citrulli. The resistance status of the accessions was reconfirmed via bioassay (Fig. 6) as previously reported with minor modifications [86]. Plants at the 3-5 true-leaf stage (4-5 weeks old) were sprayed with bacterial suspensions until runoff in a greenhouse at $22 \pm 2{ }^{\circ} \mathrm{C}$ with a relative humidity of $96 \%$. Plants were re-inoculated $3 \mathrm{~d}$ after the first inoculation to ensure that no plants had avoided inoculation and to eliminate false positives. Leaf samples from three

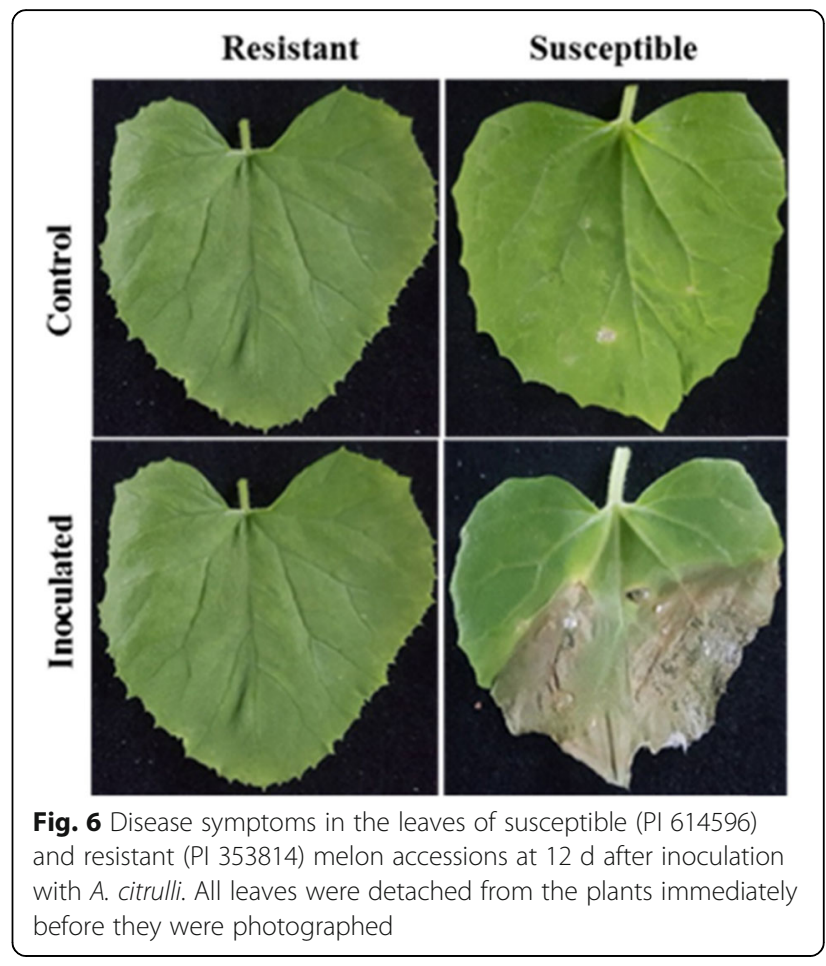

biological replicates were collected at different time points $(0 \mathrm{~h}, 12 \mathrm{~h}, 1 \mathrm{~d}, 3 \mathrm{~d}$, and $6 \mathrm{~d})$, immediately immersed in liquid nitrogen, and stored at $-80^{\circ} \mathrm{C}$ for RNA extraction and cDNA synthesis.

\section{Total RNA isolation and CDNA synthesis}

The melon leaves were ground to a powder in liquid nitrogen, and $100 \mathrm{mg}$ of each sample with three biological replicates was subjected to total RNA extraction using the RNeasy Mini kit (Qiagen, Valencia, CA) following the manufacturer's instructions. Firststrand cDNA was synthesized from total RNA with a SuperScript III First-Strand Synthesis System kit (Invitrogen, Gaithersburg, MD).

\section{Identification and in silico analysis of melon $R$-genes}

Genomic information for all $70 R$-genes, as reported in the improved assembly and annotated genome of melon [44], was retrieved from the cucurbit genomic database (http://cucurbitgenomics.org) (Additional file 1: Table S1). The genes were subjected to a series of in silico analyses such as exon-intron structure, motif distribution, domain organization, chromosomal mapping, and microsynteny analyses (for specific analytical tools, see the Results section).

\section{Primer design and quantitative RT-PCR analysis}

Gene-specific primers for quantitative RT-PCR (qRTPCR) were designed using Primer3Plus (https://primer3 plus.com/cgibin/dev/primer3plus.cgi) (Table 1). The 
expression patterns of the $R$-genes were analyzed by qRT-PCR in a LightCycler instrument (Roche, Mannheim, Germany) following the manufacturer's instructions. The reactions were performed in a $10 \mu \mathrm{L}$ volume consisting of $5 \mu \mathrm{L}$ of $2 \mathrm{x}$ qPCRBIO SyGreen Mix Lo-ROX (PCR Biosystems, London, UK), 5 pmol of primers, and cDNA template diluted to the appropriate concentrations. The PCR conditions were as follows: $5 \mathrm{~min}$ at $95^{\circ} \mathrm{C}$, followed by 3-step amplifications at $95^{\circ} \mathrm{C}$ for $15 \mathrm{~s}$, $56^{\circ} \mathrm{C}$ for $15 \mathrm{~s}$ and $72{ }^{\circ} \mathrm{C}$ for $20 \mathrm{~s}$ for 45 cycles. The mean expression levels of relevant genes were calculated by the $2^{-\Delta \Delta C t}$ method [87] using the average value of three reference genes $[2,8,88]$ as internal control.

\section{Statistical analysis}

Analysis of variance (ANOVA) and significance tests were carried out using the normalized gene expression values with MINITAB17 software (Minitab Inc., State College, PA, USA). Tukey's pairwise comparison test was employed to determine the mean separation of expression values. $p$ values indicate statistically significant variations of expression.

\section{Supplementary information}

Supplementary information accompanies this paper at https://doi.org/10. 1186/s12863-020-00885-9.

Additional file 1: Table S1. Details of the primers designed for expression profiling of melon $R$-genes. Figure S1. Exon-intron structures of $R$-genes in melon genome-wide. Light red rectangles and black lines indicate exons and introns, respectively. Figure S2. Domain structures of the 70 R-genes in melon. The conserved domains were identified using the NCBI Conserved Domain Database (CDD) (https://www.ncbi.nlm.nih. gov/Structure/bwrpsb/bwrpsb.cgi). Detailed descriptions of these domains are provided in Table 2. Specific domains in each protein are shown in the diagram. Figure S3. Gene expression profiles of resistant and susceptible melon accessions at different time points normalized to melon Actin expression (CmACT7, $149 \mathrm{bp}$ ), as determined by qRT-PCR analysis.

\section{Abbreviations}

A. citrulli: Acidovorax citrulli; BFB: Bacterial fruit blotch; R-genes: Resistance genes; avr: Avirulence; Fig: Figure; Chr: Chromosome; CDS: Coding Sequence; bp: Base pair; AA: Amino Acid; LRR: Leucine-rich repeat; NBS-LRR: Nucleotidebinding site leucine-rich repeat; TIR: Toll/interleukin-1 receptor homology; TIR: NBS-LRR- Toll/interleukin-1 receptor homology nucleotide-binding site leucine-rich repeat; NB-ARC: Nucleotide-binding adaptor shared by APAF-1, R proteins and CED-4; CC: Coiled-coil domain; RLK: Protein kinase; DUF: Domain of unknown function

\section{Acknowledgments}

We thank the U.S. National Plant Germplasm System, USA, Korean Agricultural Culture Collection, Korea, and National Institute of Horticultural and Herbal Science, Korea for providing the melon seeds and bacterial strains.

\section{Authors' contributions}

M.R.I. designed and conducted the entire experiment, DNA extraction, performed wet lab experiments, analyzed the qRT-PCR data, interpreted the results, and wrote the first draft of the manuscript. D.M.I.J. helped with the in silico analysis, performed the bioinformatics analysis, and constructed the Figs. H.-J.J. assisted with the bioassay and PCR assays. M.R.H. comprehensively revised and finalized the manuscript. I.-S.N., H.-T.K. and J.-I.P. conceived and supervised the project. All authors read and approved the final draft of the manuscript.

\section{Funding}

This study was supported by the Golden Seed Project (Grant No. 213007-054-CG100) of the Ministry of Agriculture, Food and Rural Affairs (MAFRA), Republic of Korea.

\section{Availability of data and materials}

We declare that the dataset(s) supporting the conclusions of this article are encompassed within the article (and its additional file(s).

\section{Ethics approval and consent to participate}

The authors declare that this study conforms with the current laws of the countries in which the experiments were performed.

\section{Consent for publication}

All of the authors of this manuscript give their consent to publish the findings in BMC Genetics.

\section{Competing interests}

The authors declare that there are no conflicts of interest to publish in this journal.

\section{Author details}

'Department of Horticulture, Sunchon National University, Suncheon, Jeonnam 57922, Republic of Korea. 'Department of Biotechnology, Sher-e-Bangla Agricultural University, Dhaka 1207, Bangladesh. ${ }^{3}$ Department of Genetics and Plant Breeding, Bangladesh Agricultural University, Mymensingh 2202, Bangladesh.

Received: 25 February 2020 Accepted: 12 July 2020

Published online: 22 July 2020

\section{References}

1. Garcia-Mas J, Benjak A, Sanseverino W, Bourgeois M, Mir G, González VM, Hénaff E, Câmara F, Cozzuto L, Lowy E. The genome of melon (Cucumis melo L.). PNAS. 2012;109(29):11872-7.

2. Kong Q, Gao L, Cao L, Liu Y, Saba H, Huang Y, Bie Z. Assessment of suitable reference genes for quantitative gene expression studies in melon fruits. Front Plant Sci. 2016;7:1178.

3. Fita A, Bowen HC, Hayden RM, Nuez F, Pico B, Hammond JP. Diversity in expression of phosphorus $(P)$ responsive genes in Cucumis melo L. PLoS One. 2012;7(4):e35387.

4. Lester G, Eischen F. Beta-carotene content of postharvest orange-fleshed muskmelon fruit: effect of cultivar, growing location and fruit size. Plant Food Hum Nutr. 1996;49(3):191-7.

5. Lester GE, Crosby KM. Ascorbic acid, folic acid, and potassium content in postharvest green-flesh honeydew muskmelons: influence of cultivar, fruit size, soil type, and year. J Am Soc Hortic Sci. 2002;127(5):843-7.

6. Lester GE. Antioxidant, sugar, mineral, and phytonutrient concentrations across edible fruit tissues of orange-fleshed honeydew melon (Cucumis melo L.). J Agric Food Chem. 2008;56(10):3694-8.

7. Mascarell-Creus A, Cañizares J, Vilarrasa-Blasi J, Mora-García S, Blanca J, Gonzalez-lbeas D, Saladié M, Roig C, Deleu W, Picó-Silvent B. An oligo-based microarray offers novel transcriptomic approaches for the analysis of pathogen resistance and fruit quality traits in melon (Cucumis melo L.). BMC Genomics. 2009;10(1):467.

8. Kong Q, Yuan J, Niu P, Xie J, Jiang W, Huang Y, Bie Z. Screening suitable reference genes for normalization in reverse transcription quantitative realtime PCR analysis in melon. PLoS One. 2014;9(1):e87197.

9. Schaad NW, Postnikova E, Sechler A, Claflin LE, Vidaver AK, Jones JB, Agarkova I, Ignatov A, Dickstein E, Ramundo BA. Reclassification of subspecies of Acidovorax avenae as A. avenae (Manns 1905) Emend., A. cattleyae (Pavarino, 1911) comb. nov., A. citrulli Schaad et al., 1978 comb. nov., and proposal of A. oryzae sp. nov. Syst Appl Microbiol. 2008;31(6-8): 434-46.

10. Silva GM, Souza RM, Yan L, Júnior RS, Medeiros FH, Walcott RR. Strains of the group I lineage of Acidovorax citrulli, the causal agent of bacterial fruit 
blotch of cucurbitaceous crops, are predominant in Brazil. Phytopathology 2016;106(12):1486-94.

11. Burdman S, Kots N, Kritzman G, Kopelowitz J. Molecular, physiological, and host-range characterization of Acidovorax avenae subsp. citrulli isolates from watermelon and melon in Israel. Plant Dis. 2005;89(12):1339-47.

12. Burdman S, Walcott R. Acidovorax citrulli: generating basic and applied knowledge to tackle a global threat to the cucurbit industry. Mol Plant Pathol. 2012;13(8):805-15.

13. Bahar O, Burdman S. Bacterial fruit blotch: a threat to the cucurbit industry Isr J Plant Sci. 2010;58(1):19-31.

14. Noh J, Kim J-H, Lim JH, Kim TB, Seong MH, Jung GT, Kim JM, Cheong $\mathrm{S}-\mathrm{S}$, Oh NK, Lee W-H. Occurrence of diseases and case of clinical diagnosis on watermelon in South Korea, 2008-2012. Res Plant Dis. 2014;20(1):8-14.

15. O'brien R, Martin H. Bacterial blotch of melons caused by strains of Acidovorax avenae subsp. citrulli. Aust J Exp Agr. 1999;39(4):479-85.

16. Islam M, Hossain MR, Kim H-T, Jesse DMl, Abuyusuf M, Jung H-J, Park J-I, Nou I-S. Development of molecular markers for detection of Acidovorax citrulli strains causing bacterial fruit blotch disease in melon. Int J Mol Sci. 2019;20(11):2715

17. Carvalho FC, Santos LA, Dias RC, Mariano RL, Souza EB. Selection of watermelon genotypes for resistance to bacterial fruit blotch. Euphytica. 2013;190(2):169-80.

18. Conceição CS, Felix KCS, Mariano RL, Medeiros EV, Souza EB. Combined effect of yeast and silicon on the control of bacterial fruit blotch in melon. Sci Hortic. 2014;174:164-70.

19. de Melo EA, Rosa de Lima RM, Laranjeira D, dos Santos LA, de Omena Gusmão L, de Souza EB. Efficacy of yeast in the biocontrol of bacterial fruit blotch in melon plants. Trop Plant Pathol. 2015;40(1):56-64.

20. Schaad NW, Sowell G Jr, Goth R, Colwell R, Webb R. Pseudomonas pseudoalcaligenes subsp. citrulli subsp. nov. Int I Syst Evol Microbiol. 1978; 28(1):117-25.

21. Hopkins D. The hypothetical exam question becomes reality. Plant Dis. 1995;79:761-5.

22. Hopkins DL, Thompson CM, Hilgren J, Lovic B. Wet seed treatment with peroxyacetic acid for the control of bacterial fruit blotch and other seedborne diseases of watermelon. Plant Dis. 2003;87(12):1495-9.

23. Stephens D, Schneider R, Walcott R, Johnson C. A procedure, based on exposure to chlorine gas, for disinfesting watermelon seeds. In: Phytopathology: 2008: Amer Phytopathological Soc 3340 Pilot Knob Road, St Paul, MN 55121 USA; 2008. p. S150-1.

24. Feng J, Li J, Randhawa P, Bonde M, Schaad NW. Evaluation of seed treatments for the eradication of Acidovorax avenae subsp. citrulli from melon and watermelon seeds. Can J Plant Pathol. 2009;31 (2):180-5.

25. Wan H, Yuan W, Bo K, Shen J, Pang X, Chen J. Genome-wide analysis of NBS-encoding disease resistance genes in Cucumis sativus and phylogenetic study of NBS-encoding genes in Cucurbitaceae crops. BMC Genomics. 2013; 14(1):109.

26. Jones JD. Plant disease resistance genes: structure, function and evolution. Curr Opin Biotechnol. 1996;7(2):155-60.

27. DeYoung BJ, Innes RW. Plant NBS-LRR proteins in pathogen sensing and host defense. Nat Immunol. 2006;7(12):1243.

28. Dangl JL, Jones JD. Plant pathogens and integrated defence responses to infection. Nature. 2001;411(6839):826.

29. Ellis J, Dodds P, Pryor T. Structure, function and evolution of plant disease resistance genes. Curr Opin Plant Biol. 2000;3(4):278-84.

30. Harris CJ, Slootweg EJ, Goverse A, Baulcombe DC. Stepwise artificial evolution of a plant disease resistance gene. PNAS. 2013;110(52):21189-94.

31. Van Ooijen G, Mayr G, Kasiem MM, Albrecht M, Cornelissen BJ, Takken FL. Structure-function analysis of the NB-ARC domain of plant disease resistance proteins. J Exp Bot. 2008;59(6):1383-97.

32. Qi D, DeYoung BJ, Innes RW. Structure-function analysis of the coiled-coil and leucine-rich repeat domains of the RPS5 disease resistance protein. Plant Physiol. 2012;158(4):1819-32.

33. McHale L, Tan X, Koehl P, Michelmore RW. Plant NBS-LRR proteins: adaptable guards. Genome Biol. 2006;7(4):212.

34. Nandety RS, Caplan JL, Cavanaugh K, Perroud B, Wroblewski T, Michelmore RW, Meyers BC. The role of TIR-NBS and TIR-X proteins in plant basal defense responses. Plant Physiol. 2013;162(3):1459-72.

35. Wu Y, Zhou JM. Receptor-L ike kinases in plant innate immunity. J Integr Plant Biol. 2013;55(12):1271-86.
36. Guo S, Zhang J, Sun H, Salse J, Lucas WJ, Zhang H, Zheng Y, Mao L, Ren Y Wang Z. The draft genome of watermelon (Citrullus lanatus) and resequencing of 20 diverse accessions. Nat Genet. 2013;45(1):51.

37. Zhou T, Wang Y, Chen J-Q, Araki H, Jing Z, Jiang K, Shen J, Tian D. Genomewide identification of NBS genes in japonica rice reveals significant expansion of divergent non-TIR NBS-LRR genes. Mol Gen Genomics. 2004;271(4):402-15.

38. Monosi $B$, Wisser R, Pennill L, Hulbert $S$. Full-genome analysis of resistance gene homologues in rice. Theor Appl Genet. 2004;109(7):1434-47.

39. Lv S, Changwei Z, Tang J, Li Y, Wang Z, Jiang D, Hou X. Genome-wide analysis and identification of TIR-NBS-LRR genes in Chinese cabbage (Brassica rapa ssp. pekinensis) reveal expression patterns to TuMV infection. Physiol Mol Plant Pathol. 2015;90:89-97.

40. Song W, Wang B, Li X, Wei J, Chen L, Zhang D, Zhang W, Li R. Identification of immune related LRR-containing genes in maize (Zea mays $L$.) by genome-wide sequence analysis. Int J Genomics. 2015;2015:231358.

41. Bouktila D, Khalfallah Y, Habachi-Houimli Y, Mezghani-Khemakhem M, Makni M, Makni H. Large-scale analysis of NBS domain-encoding resistance gene analogs in Triticeae. Genet Mol Biol. 2014;37(3):598-610.

42. Meyers BC, Kozik A, Griego A, Kuang H, Michelmore RW. Genome-wide analysis of NBS-LRR-encoding genes in Arabidopsis. Plant Cell. 2003;15(4):809-34.

43. Lee S-Y, Seo J-S, Rodriguez-Lanetty M, Lee D-H. Comparative analysis of superfamilies of NBS-encoding disease resistance gene analogs in cultivated and wild apple species. Mol Gen Genomics. 2003;269(1):101-8.

44. Ruggieri V, Alexiou KG, Morata J, Argyris J, Pujol M, Yano R, Nonaka S, Ezura $H$, Latrasse D, Boualem A. An improved assembly and annotation of the melon (Cucumis melo L.) reference genome. Sci Rep. 2018;8(1):8088.

45. Natarajan S, Kim H-T, Thamilarasan SK, Veerappan K, Park J-I, Nou I-S. Whole genome re-sequencing and characterization of powdery mildew diseaseassociated allelic variation in melon. PLoS One. 2016;11(6):e0157524.

46. Ng A, Xavier RJ. Leucine-rich repeat (LRR) proteins: integrators of pattern recognition and signaling in immunity. Autophagy. 2011;7(9):1082-4.

47. Bai J, Pennill LA, Ning J, Lee SW, Ramalingam J, Webb CA, Zhao B, Sun $\mathrm{Q}$ Nelson JC, Leach JE. Diversity in nucleotide binding site-leucine-rich repeat genes in cereals. Genome Res. 2002;12(12):1871-84.

48. Jebanathirajah JA, Peri S, Pandey A. Toll and interleukin-1 receptor (TIR) domain-containing proteins in plants: a genomic perspective. Trends Plant Sci. 2002; $7(9): 388-91$.

49. Rairdan GJ, Collier SM, Sacco MA, Baldwin TT, Boettrich T, Moffett P. The coiled-coil and nucleotide binding domains of the potato Rx disease resistance protein function in pathogen recognition and signaling. Plant Cell. 2008;20(3):739-51.

50. Goff KE, Ramonell KM. The role and regulation of receptor-like kinases in plant defense. Gene Regul Syst Biol. 2007;1:117762500700100015.

51. Gómez-Gómez L, Boller T. FLS2: an LRR receptor-like kinase involved in the perception of the bacterial elicitor flagellin in Arabidopsis. Mol Cell. 2000; 5(6):1003-11.

52. Shiu S-H, Bleecker AB. Plant receptor-like kinase gene family: diversity, function, and signaling. Sci STKE. 2001;2001(113):re22.

53. Gu Y, Innes RW. The KEEP ON GOING protein of Arabidopsis recruits the ENHANCED DISEASE RESISTANCE1 protein to trans-Golgi network/early endosome vesicles. Plant Physiol. 2011;155(4):1827-38.

54. Yang Q, Niu X, Tian X, Zhang X, Cong J, Wang R, Zhang G, Li G Comprehensive genomic analysis of the DUF4228 gene family in land plants and expression profiling of ATDUF4228 under abiotic stresses. BMC Genomics. 2020:21(1):1-16.

55. Slootweg E, Koropacka K, Roosien J, Dees R, Overmars H, Lankhorst RK, van Schaik C, Pomp R, Bouwman L, Helder J. Sequence exchange between homologous NB-LRR genes converts virus resistance into nematode resistance, and vice versa. Plant Physiol. 2017;175(1):498-510.

56. Bonas U, Van den Ackerveken G. Gene-for-gene interactions: bacterial avirulence proteins specify plant disease resistance. Curr Opin Microbiol. 1999;2(1):94-8.

57. van Leeuwen H, Garcia-Mas J, Coca M, Puigdoménech P, Monfort A. Analysis of the melon genome in regions encompassing TIR-NBS-LRR resistance genes. Mol Gen Genomics. 2005;273(3):240-51.

58. Kourelis J, van der Hoorn RA. Defended to the nines: 25 years of resistance gene cloning identifies nine mechanisms for R protein function. Plant Cell. 2018;30(2):285-99.

59. Marone D, Russo MA, Laidò G, De Leonardis AM, Mastrangelo AM. Plant nucleotide binding site-leucine-rich repeat (NBS-LRR) genes: active guardians in host defense responses. Int J Mol Sci. 2013;14(4):7302-26. 
60. Van Leeuwen $H$, Monfort A, Zhang $H-B$, Puigdomènech $P$. Identification and characterisation of a melon genomic region containing a resistance gene cluster from a constructed BAC library. Microcolinearity between Cucumis melo and Arabidopsis thaliana. Plant Mol. Biol. 2003;51(5):703-18.

61. Garcia-Mas J, van Leeuwen $H$, Monfort $A$, de Vicente MC, Puigdomènech $P$, Arús P. Cloning and mapping of resistance gene homologues in melon. Plant Sci. 2001;161(1):165-72.

62. Büschges $R$, Hollricher $K$, Panstruga $R$, Simons $G$, Wolter $M$, Frijters $A$, van Daelen R, van der Lee T, Diergaarde P, Groenendijk J. The barley Mlo gene: a novel control element of plant pathogen resistance. Cell. 1997:88(5):695-705

63. Loh Y-T, Martin GB. The disease-resistance gene Pto and the fenthionsensitivity gene fen encode closely related functional protein kinases. PNAS. 1995;92(10):4181-4.

64. Hulbert SH, Webb CA, Smith SM, Sun Q. Resistance gene complexes: evolution and utilization. Annu Rev Phytopathol. 2001;39(1):285-312.

65. Wang Y, Tan J, Wu Z, VandenLangenberg K, Wehner TC, Wen C, Zheng X, Owens K, Thornton A, Bang HH. STAYGREEN, STAY HEALTHY: a loss-ofsusceptibility mutation in the STAYGREEN gene provides durable, broadspectrum disease resistances for over 50 years of US cucumber production. New Phytol. 2019;221(1):415-30.

66. Kato T, Hatakeyama K, Fukino N, Matsumoto S. Fine mapping of the clubroot resistance gene $\mathrm{CRb}$ and development of a useful selectable marker in Brassica rapa. Breed.Sci. 2013;63(1):116-24.

67. Li L, Luo Y, Chen B, Xu K, Zhang F, Li H, Huang Q, Xiao X, Zhang T, Hu J. A genome-wide association study reveals new loci for resistance to clubroot disease in Brassica napus. Front Plant Sci. 2016;7:1483.

68. Delourme R, Laperche A, Bouchet A-S, Jubault M, Paillard S, ManzanaresDauleux M-J, Nesi N. Genes and quantitative trait loci mapping for major agronomic traits in Brassica napus L. In: The Brassica napus genome. In: Springer; 2018. p. 41-85.

69. González VM, Aventín N, Centeno E, Puigdomènech P. Interspecific and intraspecific gene variability in a 1-Mb region containing the highest density of NBS-LRR genes found in the melon genome. BMC Genomics. 2014;15(1):1131.

70. Lecoq $H_{1}$ Pitrat M:Effect on cucumber mosaic virus incidence of the cultivation of partially resistant muskmelon cultivars. In: IV Conference on recent Advances in Vegetable Virus Research 127: 1982; 1982: 137-146.

71. Oumouloud A, Arnedo-Andres MS, Gonzalez-Torres R, Alvarez JM. Development of molecular markers linked to the Fom-1 locus for resistance to Fusarium race 2 in melon. Euphytica. 2008;164(2):347-56.

72. Dogimont C, Chovelon V, Pauquet J, Boualem A, Bendahmane A. The V at locus encodes for a CC-NBS-LRR protein that confers resistance to Aphis gossypii infestation and A. gossypii-mediated virus resistance. Plant J. 2014; 80(6):993-1004.

73. Wang $\mathrm{Y}-\mathrm{H}$, Choi W, Thomas $\mathrm{CE}$, Dean RA. Cloning of disease-resistance homologues in end sequences of BAC clones linked to Fom-2, a gene conferring resistance to Fusarium wilt in melon (Cucumis melo L.). Genome. 2002:45(3):473-80.

74. Islam MR, Hossain MR, Kim H-T, Nath UK, Abuyusuf M, Jung H-J, Park J-I, Nou I-S. Molecular characterization of Acidovorax citrulli strain NIHHS15-280 causing bacterial fruit blotch disease in Korea and screening of resistance sources in melon. Hortic Environ Biotechnol. 2019;61(1):1-12.

75. Hong C, Wei-Ping K, Jun-Feng L. Comparative transcriptome analysis of powdery mildew resistance between two melon (Cucumis melo L) with different thickness Peel. BioRxiv. 2019;541391.

76. Polonio Á, Pineda M, Bautista R, Martínez-Cruz J, Pérez-Bueno ML, Barón M, Pérez-García A. RNA-seq analysis and fluorescence imaging of melon powdery mildew disease reveal an orchestrated reprogramming of host physiology. Sci Rep. 2019;9(1):7978.

77. Silvia Sebastiani M, Bagnaresi P, Sestili S, Biselli C, Zechini A, Orrù L, Cattivelli $\mathrm{L}$, Ficcadenti N. Transcriptome analysis of the melon-Fusarium oxysporum $\mathrm{f}$. sp. melonis race 1.2 pathosystem in susceptible and resistant plants. Front Plant Sci. 2017:8:362

78. Wang P, Wu H, Zhao G, He Y, Kong W, Zhang J, Liu S, Liu M, Hu K, Liu L. Transcriptome analysis clarified genes involved in resistance to Phytophthora capsici in melon. PLoS One. 2020;15(2):e0227284.

79. Zhu Q, Gao P, Wan Y, Cui H, Fan C, Liu S, Luan F. Comparative transcriptome profiling of genes and pathways related to resistance against powdery mildew in two contrasting melon genotypes. Sci Hortic. 2018;227: 169-80.
80. Zhou S, Jing Z, Shi J. Genome-wide identification, characterization, and expression analysis of the MLO gene family in Cucumis sativus. Genet Mol Res. 2013;12(4):6565-78.

81. Hassan M, Rahim M, Natarajan S, Robin A, Kim H-T, Park J-I, Nou I-S. Gummy stem blight resistance in melon: inheritance pattern and development of molecular markers. Int J Mol Sci. 2018;19(10):2914.

82. Whitham S, Dinesh-Kumar S, Choi D, Hehl R, Corr C, Baker B. The product of the tobacco mosaic virus resistance gene $\mathrm{N}$ : similarity to toll and the interleukin-1 receptor. Cell. 1994;78(6):1101-15.

83. Islam M, Hossain MR, Jesse DMI, Jung H-J, Kim H-T, Park J-I, Nou I-S. Development of Molecular Marker Linked with Bacterial Fruit Blotch Resistance in Melon (Cucumis melo L.). Genes. 2020;11(2):220.

84. Schaad N, Jones J, Chun W. Laboratory guide for the identification of plant pathogenic bacteria. Paul, MN: Amer Phytopathol. Soc; 2001.

85. Wechter WP, Levi A, Ling K-S, Kousik C, Block CC. Identification of resistance to Acidovorax avenae subsp. citrulli among melon (Cucumis spp.) plant introductions. Hortscience. 2011;46(2):207-12.

86. Bahar O, Kritzman G, Burdman S. Bacterial fruit blotch of melon: screens for disease tolerance and role of seed transmission in pathogenicity. Eur J Plant Pathol. 2009;123(1):71-83.

87. Livak KJ, Schmittgen TD. Analysis of relative gene expression data using real-time quantitative PCR and the $2-\Delta \Delta C T$ method. Methods. 2001;25(4): 402-8.

88. Rachmawati Y, Daryono BS, Aristya GR. Molecular characters of melon (Cucumis melo L."Tacapa") in response to karst critical land. In: AIP Conference Proceedings: 2017: AIP Publishing LLC; 2017. p. 020030

\section{Publisher's Note}

Springer Nature remains neutral with regard to jurisdictional claims in published maps and institutional affiliations.

Ready to submit your research? Choose BMC and benefit from:

- fast, convenient online submission

- thorough peer review by experienced researchers in your field

- rapid publication on acceptance

- support for research data, including large and complex data types

- gold Open Access which fosters wider collaboration and increased citations

- maximum visibility for your research: over $100 \mathrm{M}$ website views per year

At BMC, research is always in progress.

Learn more biomedcentral.com/submissions 